\title{
Phase Transformation, Technological Properties and Microstructure of Fired Products Based on Clay-Dolomite Mixtures
}

\author{
B. S. Gonidanga ${ }^{1,2,3}{ }^{*}$, D. Njoya ${ }^{1 *}$, G. Lecomte-Nana ${ }^{2}$, D. Njopwouo ${ }^{1}$ \\ ${ }^{1}$ Laboratory of Applied Inorganic Chemistry, University of Yaounde 1, Yaounde, Cameroon \\ ${ }^{2}$ IRCER-University of Limoges, Limoges, France \\ ${ }^{3}$ Water Management, Lavoisier Hydrosciences Laboratory, University of Bangui, Faculty of Sciences, \\ Bangui, Central African Republic \\ Email: *sergesogony@yahoo.fr, *dayirou2000@yahoo.fr, *dnjoya@uy1.uninet.cm
}

How to cite this paper: Gonidanga, B.S., Njoya, D., Lecomte-Nana, G. and Njopwouo, D. (2019) Phase Transformation, Technological Properties and Microstructure of Fired Products Based on Clay-Dolomite Mixtures. Journal of Materials Science and Chemical Engineering, 7, 1-14.

https://doi.org/10.4236/msce.2019.711001

Received: September 30, 2019

Accepted: November 8, 2019

Published: November 11, 2019

Copyright $\odot 2019$ by author(s) and Scientific Research Publishing Inc. This work is licensed under the Creative Commons Attribution International License (CC BY 4.0).

http://creativecommons.org/licenses/by/4.0/

\begin{abstract}
The present work reports the effect of carbonate addition to iron rich kaolinite on the phase transformation during firing. Mineralogical, thermal (including DTA-TGA and dilatometric) and physico-mechanical analyses were performed on fired product made from a mixture of kaolinite and $8 \%$ by mass of dolomite. The firing temperatures used are $920^{\circ} \mathrm{C}, 1050^{\circ} \mathrm{C}, 1150^{\circ} \mathrm{C}$, $1200^{\circ} \mathrm{C}$ and $1250^{\circ} \mathrm{C}$. The major mineral phases formed during firing are mullite, cristobalite and hematite associated to gehlenite and anorthite at temperature $>1150^{\circ} \mathrm{C}$. Their presence induces increased densification of the product that results in an increased in the flexural strength up to $1150^{\circ} \mathrm{C}$. Beyond this temperature, increase glassy phase formation together with hematite development, induce a decrease of the flexural strength as well as the porosity and water adsorption. The SEM observations show that primary mullite is formed as from $1150^{\circ} \mathrm{C}$. The EDS analysis from SEM is coherent with the chemical and the mineralogical analyses from XRD. The overall analyses indicate that the addition of dolomite at $8 \%$ by mass is favorable to vitreous ceramic formation as from $1050^{\circ} \mathrm{C}$.
\end{abstract}

\section{Keywords}

Clayey Materials, Dolomite, Kaolinite, Phase Transformation, Microstructures

\section{Introduction}

A mineral material, upon thermal treatment, undergoes chemical and structural modification. These include dehydration, dehydroxylation, decomposition, new 
phase formation. These mineralogical transformations are influenced by the chemical composition, the initial mineralogical composition; the particles size, the firing temperature, the heating rate and the soaking time [1] [2] [3].

The phase transformation of clay containing calcite is subject of many reported studies [4]-[9]. Usually, for clayey material with low iron impurities $(\mathrm{Fe}<$ $5 \%$ ), about $50 \% \mathrm{SiO}_{2}, 15 \% \mathrm{Al}_{2} \mathrm{O}_{3}$ and $10 \%$ carbonate, the new phases formed are gehlénite, wollastonite, anorthite, cordierite, larnite, périclase, akermamite, forstérite, spinell and monticellite.

In Central Africa Republic (CAR), carbonate, schist, quartzite, micashiste and amphibole are found in the neighborhood of Bangui [10] [11] [12] [13]. The valorization of the carbonate could be achieved in clay-carbonate mixture for improved ceramic products making. Such a mixture could influence the properties of fired products or induced different heating pathway.

This study evaluates the influence of carbonate addition to kaolinitic clay from Bimbo in the elaboration of fired products. In particular, this work aim is to analyze the influence of carbonate addition to iron rich kaolinite clay, on phase transformations during thermal treatment and its influence on the products densification.

To this end, several technics, including X-ray diffraction, Thermal analysis, TGA-DTA; Dilatometry; Scanning electron microscope (SEM), X-ray fluorescence, are used to analyze fired bricks at temperature ranging from $900^{\circ} \mathrm{C}$ to $1200^{\circ} \mathrm{C}$. Technological properties such as water adsorption, porosity and flexural strength were evaluated.

\section{Materials and Methods}

The clayey material used (BIM1) was collected from Bimbo, a locality of the Ombella-M'Poko division, situated at about $8 \mathrm{~km}$ in the South-west of Bangui. This deposit altitude is $340 \mathrm{~m}$ and the GPS coordinates are as follow: $04^{\circ} 19^{\prime} 17^{\prime \prime}$ North latitude and $18^{\circ} 31^{\prime} 57^{\prime \prime}$ East longitude. The dolomite (DO) was collected at Dogbe, a locality situated at about $100 \mathrm{~km}$ from Bangui with the following GPS coordinates $05^{\circ} 05^{\prime} \mathrm{N}$ et $18^{\circ} 33^{\prime} \mathrm{E}$.

The chemical and the mineralogical composition of the clay are given in $\mathrm{Ta}$ ble 1 [14]. The clay material is iron rich with a tenor of $9 \%$. The $\mathrm{SiO}_{2}$ and $\mathrm{Al}_{2} \mathrm{O}_{3}$ contents are respectively, $50 \%$ and $25 \%$. In a previous work [14], the fired brick, at $1100^{\circ} \mathrm{C}$, of this sample exhibits technological properties of interest (flexural strength $15 \mathrm{MPa}$ and a porosity of $26 \%$ ).

In this study, the addition of dolomite in the formulation will be $8 \%$ (mass basis) as proposed by a study by [15], to ensure quality mechanical response. This formulation will be denoted M-8 although the study.

After ambient drying in the laboratory, the samples are crush and sieved over a $100 \mu \mathrm{m}$ mesh for BIM1 and an $80 \mu \mathrm{m}$ mesh for dolomite (DO). A suspension of the mixture is then prepared and manually agitated for $5 \mathrm{~min}$. The paste is left for evaporation at $60^{\circ} \mathrm{C}$ in an oven for $24 \mathrm{~h}$; the temperature is raised to $105^{\circ} \mathrm{C}$, 
Table 1. Chemical and mineralogical composition of BIM1.

\begin{tabular}{|c|c|c|c|}
\hline \multicolumn{2}{|c|}{ Chemical Composition } & \multicolumn{2}{|c|}{ Mineralogical Composition } \\
\hline Oxide & Tenor (\%) & Mineral & Tenor (\%) \\
\hline $\mathrm{SiO}_{2}$ & 50.20 & Kaolinite & 61 \\
\hline $\mathrm{Al}_{2} \mathrm{O}_{3}$ & 25.42 & Illite & 5.05 \\
\hline $\mathrm{Fe}_{2} \mathrm{O}_{3}$ & 9.33 & Quartz & 19.67 \\
\hline $\mathrm{MnO}$ & $<\mathrm{ld}$ & Goethite & 10.38 \\
\hline $\mathrm{MgO}$ & 0.38 & Anatase & 2.03 \\
\hline $\mathrm{CaO}$ & 0.07 & Total & 98.83 \\
\hline $\mathrm{Na}_{2} \mathrm{O}$ & 0.08 & Undetermined & 0.7 \\
\hline $\mathrm{K}_{2} \mathrm{O}$ & 1.0 & & \\
\hline $\mathrm{TiO}_{2}$ & 2.03 & & \\
\hline $\mathrm{P}_{2} \mathrm{O}_{5}$ & 0.06 & & \\
\hline $\mathrm{NiO}$ & 0.02 & & \\
\hline $\mathrm{LOI}\left(1050^{\circ} \mathrm{C}\right)$ & 11.24 & & \\
\hline Total & 99.83 & & \\
\hline $\mathrm{SIO}_{2} / \mathrm{Al}_{2} \mathrm{O}_{3}$ & 1.97 & & \\
\hline
\end{tabular}

for the paste to dry to constant weight. The dried cake is then crushed and sieved over a $100 \mu \mathrm{m}$ mesh.

For the characterization of the dolomite, X-ray diffraction (XRD), infra-red and differential scanning calorimetry (DSC) are used. X-ray fluorescence on a PANalytical Zetium equipment is used for the chemical analysis. The dolomite material is fused in lithium metaborate $\left(\mathrm{LiBO}_{2}\right)$ prior to the analysis. The loss on ignition (LOI) is access by weighing the sample heated between $105^{\circ} \mathrm{C}$ and $1050^{\circ} \mathrm{C}$.

The XRD pattern is acquired on a BRUKER D8 Advance, using a copper radiation in $2 \theta$ range from a $5^{\circ}$ to $60^{\circ}$ using a step size of $0.02^{\circ} / \mathrm{min}$.

Infra-red spectra are registered on a Perkin Elmer equipment from $400-4000$ $\mathrm{cm}^{-1}$. A KBr pellet containing about $15 \%$ of the sample is used for the acquisition in attenuated total reflectance mode.

Differential scanning calorimetry (DSC) and thermogravimetric analysis (TGA) were obtained on a couple DCS-TG analyzer, SETARAM TG-DSC Labsys Evolution, from room temperature to $1200^{\circ} \mathrm{C}$ at a heating rate of $5^{\circ} \mathrm{C} / \mathrm{min}$. About 25 $\mathrm{mg}$ of powdered material is used. An empty alumina crucible is used as reference.

Dilatometric analysis is done using cylindrical test sample of $10 \mathrm{~mm}$ diameter on a SERETAM TMA SETSYS Evo equipment. The analysis is conducted from room temperature to $1200^{\circ} \mathrm{C}$. The test samples are obtained by pressing $2 \mathrm{~g}$ of powder using a SPECAC hydraulic press at $30 \mathrm{MPa}$.

Physical characterizations of fired products were done on parallelepiped sam- 
ples for linear shrinkage and on cylindrical pastel for water adsorption and porosity. All the characterizations are done following the norm NF EN ISO 10545-3, 1997-12.

The flexural strength was acquired using a three point bending electrohydraulic press $\left(\mathrm{M} \& \mathrm{O}\right.$, type $\left.11.50 \mathrm{~N}^{\circ} 21\right)$. The parallelepiped sample is submitted to a continuous progressive load up to rupture.

For the SEM analysis, the sample is coated with platinum in order to render their surface conductive electrons. The micrographs are obtained using FEIQUANTA EG ESEM 450 equipment operating under at $15 \mathrm{kV}$.

\section{Results and Discussion}

\subsection{Dolomitic (D0) Characterization}

The chemical analysis is given in Table 2. Figure 1, Figure 2 and Figure 3 are respectively given the XRD pattern, the FTIR spectra and the thermal analysis by DSC.

The oxides $\mathrm{CaO}$ and $\mathrm{MgO}$ are the main constituents of the dolomite materials (Table 2) with silica as associate components. The loss on ignition is high (43\%) and closed to the values usually found in the literature [16] [17] [18]. From XRD analysis (Figure 1), the main mineral is dolomite associated to quartz and calcite.

The infrared spectra (Figure 2) show band characteristics of dolomite at 3417 $3010-2900-2638-2530-1825-1440-1100-1035-878$ et $730 \mathrm{~cm}^{-1}$ [19] [20].

Table 2. Chemical analysis of the dolomitic material (DO).

\begin{tabular}{lllllllllllllll}
\hline & $\mathrm{SiO}_{2}$ & $\mathrm{Al}_{2} \mathrm{O}_{3}$ & $\mathrm{Fe}_{2} \mathrm{O}_{3}$ & $\mathrm{MnO}$ & $\mathrm{MgO}$ & $\mathrm{CaO}$ & $\mathrm{Na}_{2} \mathrm{O}$ & $\mathrm{K}_{2} \mathrm{O}$ & $\mathrm{TiO}_{2}$ & $\mathrm{P}_{2} \mathrm{O}_{5}$ & $\mathrm{NiO}$ & $\mathrm{LOI}$ & Total \\
\hline $\mathrm{DO}$ & 08.13 & 0.37 & 0.63 & 0.06 & 19.10 & 28.5 & $<\mathrm{d} .1$ & 0.14 & $<\mathrm{d} .1$ & 0.08 & $<\mathrm{d} .1$ & 43.00 & 100.1
\end{tabular}

d.l = detection limit; LOI: loss on ignition (here at $\left.1050^{\circ} \mathrm{C}\right)$.

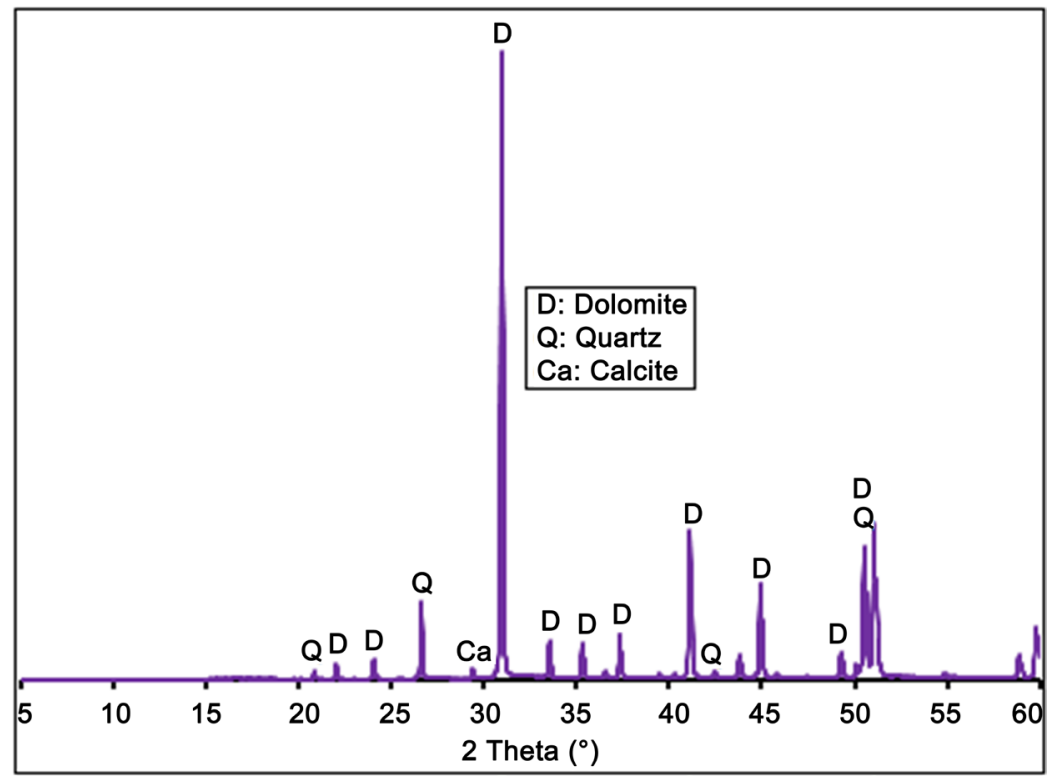

Figure 1. XRD pattern of the dolomitic material. 


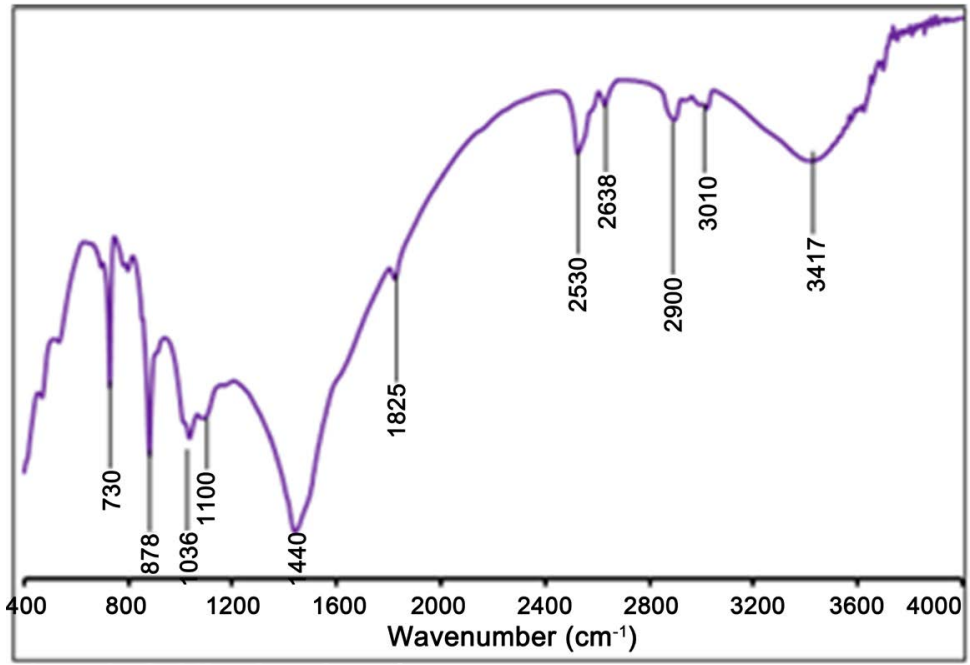

Figure 2. Infra-red spectra of the dolomitic material.

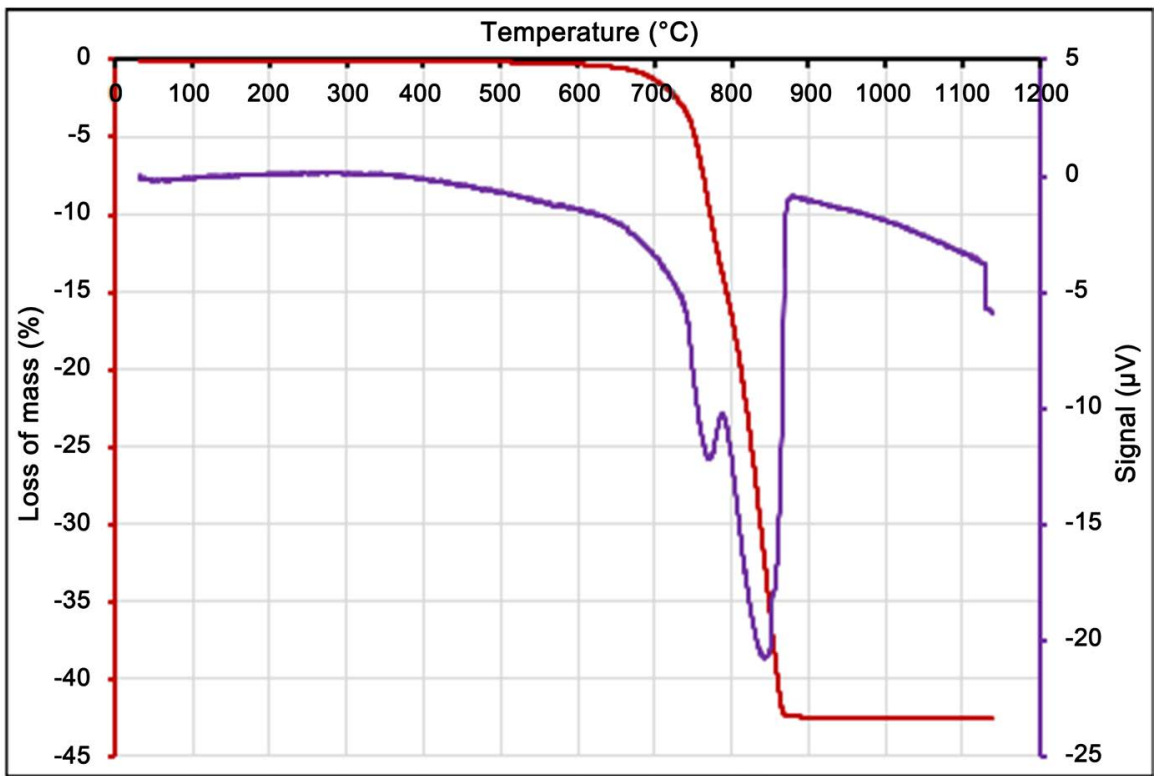

Figure 3. TGA-DTA graph of the dolomitic material.

Si-O bonds are located at 1100 and $900 \mathrm{~cm}^{-1}$.

The dolomite thermal analysis graph (Figure 3) shows two endothermic peaks, on the DTG curve, that are related to the decomposition of dolomite in two stages. The percentage loss associated to this decomposition is estimated at about $42.57 \%$, which is in accordance with the loss of ignition (43\%) from the chemical analysis (Table 2).

\subsection{Thermo-Dilatometric Characteristic of the Mixture (M-8)}

The thermal analysis curves of the mixture (M-8) are presented in Figure 4. At $\mathrm{T}$ $<800^{\circ} \mathrm{C}$, the deshydroxylation of the kaolinite and the decomposition of the dolomite are registered. In this range the various mass changes are easily associable to each material as if it was alone. However, these changes occurred at lowered 
temperatures, compare to each material undergoing thermal decomposition alone. This difference is probably due to associate minerals in the mixture [21]. At $573^{\circ} \mathrm{C}$, the conversion of quartz $\alpha$ to quartz $\beta$ is observed through the endothermic peak on the DTA. The exothermic peak at $830^{\circ} \mathrm{C}$ is associated to the formation of new mineral phase from metakoalinite and decomposition product of dolomite [18]. At $950^{\circ} \mathrm{C}$, the reorganization of metakaolinite into a spinel phase is observed this spinel is converted to mullite around $1100^{\circ} \mathrm{C}$ as shown by the exothermic peak at this temperature.

Dilatometric curve of BIM-1 and mixture M-8 are presented in Figure 5. The behavior of both systems is similar and characteristic of clayey materials [22] [23]. On the M-8 curve a horizontal trace is registered from the beginning up to almost $500^{\circ} \mathrm{C}$. In this zone no transformations occur. Between $500^{\circ} \mathrm{C}$ and $600^{\circ} \mathrm{C}$, a small shrinkage is registered. This change is associated with the dehydroxylation

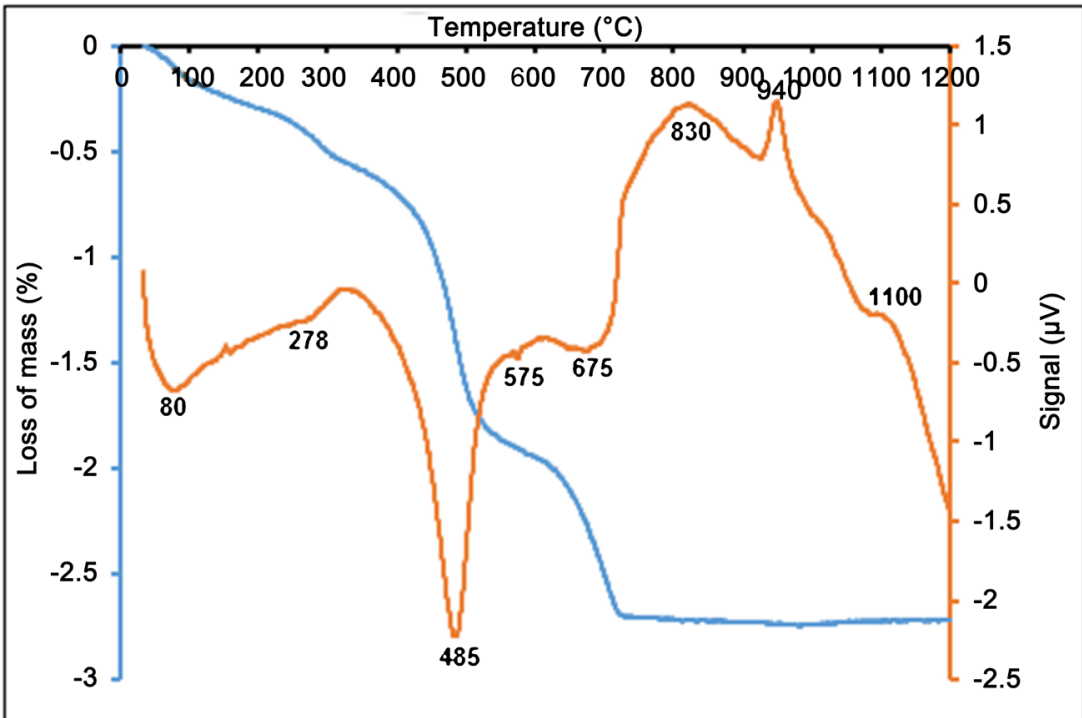

Figure 4. DTA/TGA curve of the M-8 mixture.

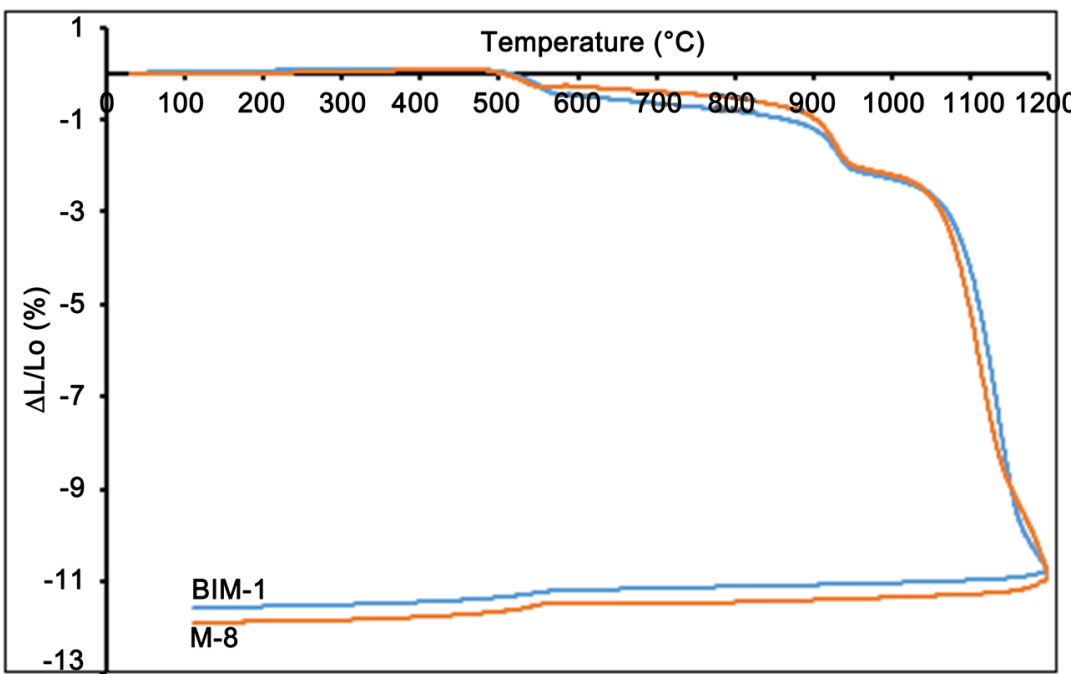

Figure 5. Dilatometric curves of the clayey material BIM-1 and the mixture M-8. 
of kaolinite which is converted to metakaolinite and the dehydroxylation of the $\mathrm{Mg}(\mathrm{OH})_{2}$ from the dolomitic material. The shrinkage between $900^{\circ} \mathrm{C}$ and $1000^{\circ} \mathrm{C}$ is associated to the structural reorganization of the metakaolinite into mullite. This conversion is generally associated to an increase densification [24] [25]. From the graphs, the presence of the dolomite in the mixture induced an increase of the mass loss from $11.5 \%$ in BIM-1 alone to $11.9 \%$ in the mixture.

\subsection{Phase Transformation during Thermal Treatment}

This phase transformation was studied using XRD and the firing temperature is chosen based on the exothermic peaks in the DTA/TGA curves. The patterns are presented in Figure 6.

The various new-phase evolutions are illustrated in Table 3. As the firing

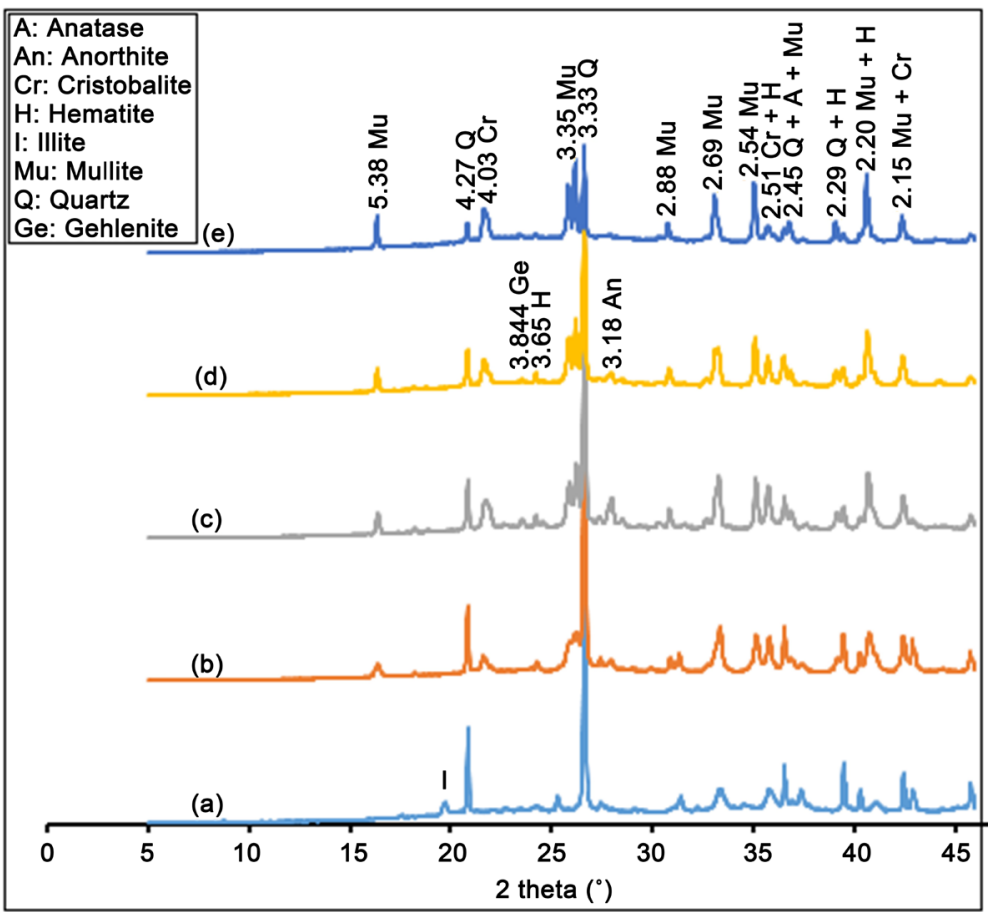

Figure 6. XRD patterns of firing products of M-8: (a) $920^{\circ} \mathrm{C}$ (b) $1050^{\circ} \mathrm{C}$ (c) $1150^{\circ} \mathrm{C}$ (d) $1200^{\circ} \mathrm{C}(\mathrm{e}) 1250^{\circ} \mathrm{C}$

Table 3. Phase evolution during thermal treatment.

\begin{tabular}{|c|c|c|c|c|c|}
\hline \multirow[b]{2}{*}{$\mathrm{T}\left({ }^{\circ} \mathrm{C}\right)$} & \multicolumn{5}{|c|}{ Phase } \\
\hline & An & $\mathrm{Cr}$ & $\mathrm{G}$ & & $\mathrm{Mu}$ \\
\hline 920 & & & & & \\
\hline 1050 & & & & & \\
\hline 1150 & & & & & \\
\hline 1200 & & & & & \\
\hline 1250 & & & & & \\
\hline
\end{tabular}


temperature increase, the intensities of the main reflections of quartz (3.33 and $4.27 \AA$ ) are lowered while that of mullite ( 3.35 and $5.38 \AA$ ), cristobalite (4.03 $\AA$ ) and hematite (2.69 and $2.51 \AA$ ) increase. Hematite is formed from the goethite transformation around $300^{\circ} \mathrm{C}$. Gehlenite and anorthite that appear at $1050^{\circ} \mathrm{C}$, with low intensities, disappear at $1200^{\circ} \mathrm{C}$. It is suggested that the low iron oxide and liquid phase, has favored the interaction of decomposition products to formed gehlenite and anorthite. The illite reflections are no longer observable after firing at $1050^{\circ} \mathrm{C}$. The disappearance of some phases is associated to their conversion into other phases, kaolinite and illite to form mullite; their coverage by the vitreous phase form (the case of quartz) or their transformation into vitreous phases (the case of anorthite) [8]. The proposed phase transformations from the raw materials are illustrated by the following equations [26] [27]:

Between 900 and $1000^{\circ} \mathrm{C}$,

$$
\begin{aligned}
& 2\left(2 \mathrm{SiO}_{2} \cdot \mathrm{Al}_{2} \mathrm{O}_{3}\right)(\text { metakaolinite }) \\
& \rightarrow \mathrm{Si}_{3} \mathrm{Al}_{4} \mathrm{O}_{12}(\text { spinelle })+\mathrm{SiO}_{2}(\text { amorphous silica })
\end{aligned}
$$

Or $2 \mathrm{SiO}_{2} \cdot \mathrm{Al}_{2} \mathrm{O}_{3}$ (metakaolinite) $\rightarrow \Upsilon-\mathrm{Al}_{2} \mathrm{O}_{3}+\mathrm{SiO}_{2}$ (amorphous silica) when $T \geq 1050^{\circ} \mathrm{C}$,

$$
\begin{array}{ll} 
& \mathrm{Si}_{3} \mathrm{Al}_{4} \mathrm{O}_{12}(\text { spinelle })+\mathrm{SiO}_{2}(\text { amorphous silica }) \\
& \rightarrow 3 \mathrm{Al}_{2} \mathrm{O}_{3} \cdot 2 \mathrm{SiO}_{2}(\text { mullite })+2 \mathrm{SiO}_{2}(\text { amorphous silica }) \\
\text { or } & 3 \mathrm{Al}_{2} \mathrm{O}_{3}+6 \mathrm{SiO}_{2}(\text { amorphous silica }) \\
& \rightarrow 3 \mathrm{Al}_{2} \mathrm{O}_{3} \cdot 2 \mathrm{SiO}_{2}(\text { mullite })+4 \mathrm{SiO}_{2}(\text { amorphous silica }) \\
& 3 \mathrm{Al}_{2} \mathrm{O}_{3} \cdot 2 \mathrm{SiO}_{2}(\text { mullite })+4 \mathrm{SiO}_{2}(\text { amorphous silica }) \\
& \left.\left.\rightarrow 3 \mathrm{Al}_{2} \mathrm{O}_{3} \cdot 2 \mathrm{SiO}_{2} \text { (mullite }\right)+4 \mathrm{SiO}_{2} \text { (cristobalite }\right)
\end{array}
$$

Anorthite and gehlenite are formed by the reaction betwen metakaolinite (from kaolinite decomposition at about $500^{\circ} \mathrm{C}$ ) and lime (from dolomite decomposition arround $\left.700^{\circ} \mathrm{C}\right)[9]$.

For $1050^{\circ} \mathrm{C} \leq T \leq 1200^{\circ} \mathrm{C}$

$$
\begin{aligned}
& \left.\mathrm{Al}_{2} \mathrm{Si}_{2} \mathrm{O}_{7} \text { (metakaolinite }\right)+2 \mathrm{CaO}(\text { lime }) \\
& \rightarrow \mathrm{Ca}_{2} \mathrm{Al}_{2} \mathrm{SiO}_{7} \text { (gehlenite) }+\mathrm{SiO}_{2}(\text { silica })
\end{aligned}
$$

For $1150^{\circ} \mathrm{C} \leq T \leq 1200^{\circ} \mathrm{C}$

$$
\begin{aligned}
& \left.\mathrm{Ca}_{2} \mathrm{Al}_{2} \mathrm{SiO}_{7} \text { (gehlenite) }+\mathrm{Al}_{2} \mathrm{Si}_{2} \mathrm{O}_{7} \text { (metakaolinite }\right)+\mathrm{SiO}_{2}(\text { silica }) \\
& \rightarrow 2 \mathrm{CaAl}_{2} \mathrm{Si}_{2} \mathrm{O}_{8} \text { (anorthite) }
\end{aligned}
$$

\subsection{Technological Properties of the Fired Products from M-8}

The physical and mechanical characterizations of the fired products from M-8 are presented in Figure 7. The linear shrinkage increased for all the temperature (Figure 7(a)); this increase is rapid from $920^{\circ} \mathrm{C}$ to $1100^{\circ} \mathrm{C}$ and beyond $1100^{\circ} \mathrm{C}$, it is slowed. This shrinkage is associated to the transformation/rearrangement of the constituent to reach a more stable rearrangement of the particles [28]. These transformations include constituent elimination (gas formation or water removal); 


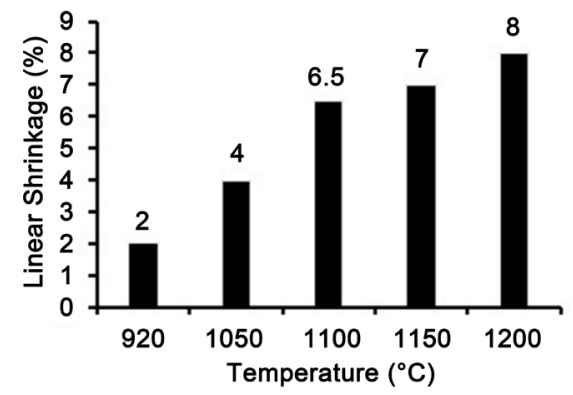

(a)

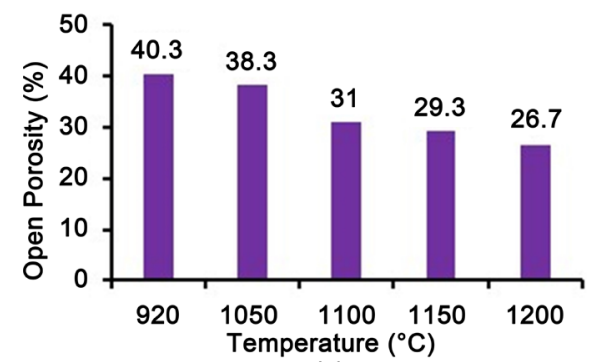

(c)

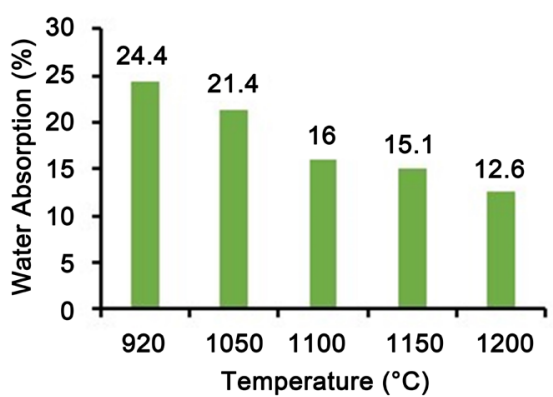

(b)

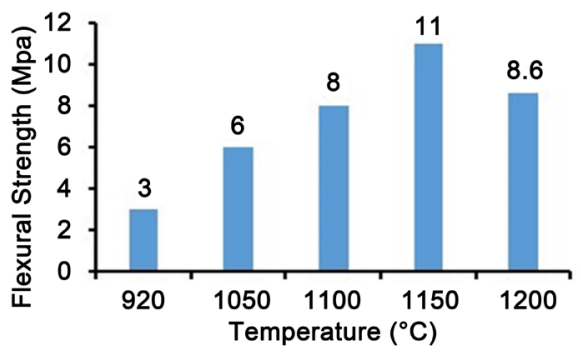

(d)

Figure 7. (a) Linear shrinkage; (b) water adsorption; (c) open porosity and (d) flexural strength of fired products from mixture M-8 at various temperatures.

structural reorganization and conversion into liquid or viscous phases. The rapid increase of the shrinkage is associated to the release of carbon dioxide from dolomite and decomposition of kaolinite, illite and goethite in the lowers firing temperature. Also, the presence of calcite influences the contraction of the product during the sintering [29]. Above $1100^{\circ} \mathrm{C}$, almost all transformations/conversion are finished whish justified the low shrinkage beyond this temperature.

The water adsorption decrease from $920^{\circ} \mathrm{C}$ to $1100^{\circ} \mathrm{C}$ (Figure $7(\mathrm{~b})$ ); same apply for the porosity (7c). These results are coherent with the decomposition of products such as illite to form vitreous phase is which the cristobalite from quartz transformations is dissolved [30]. This is coherent with the observation from XRD on which cristobalite peak is observed as from $1050^{\circ} \mathrm{C}$ and diminished when the temperature is increased as a result of its dissolution in a vitreous phase. The gran sintering and the inclusion of the vitreous phase in whole reduce the porosity as well.

The flexural strength (Figure $7(\mathrm{~d})$ ) shows an increase of the strength up to $1150^{\circ} \mathrm{C}$ and this trend is reversed at $1200^{\circ} \mathrm{C}$. The increased of the strength is coherent with the porosity reduction as a result of increased densification [30]. This densification is also coherent with the XRD results (Figure 6), where the main minerals, up to $1150^{\circ} \mathrm{C}$, are mullite cristobalite and quartz. These dense mineral induce and increase of the flexural strength. The formation of hematite crystallite, at higher temperature $\left(1200^{\circ} \mathrm{C}\right)$, cause de silico-aluminate phase to become more heterogeneous, which result in weakening of the products [7] and this justified the decrease of the flexural strength observed at $1200^{\circ} \mathrm{C}$. In addition, a formation of larger amount of glassy phase may also cause fragile product as from $1200^{\circ} \mathrm{C}[30][31]$. 


\subsection{SEM-EDS Analyses of the Fired Products}

The micrographs of the fired products from $\mathrm{M}-8$ at $1150^{\circ} \mathrm{C}$ and $1200^{\circ} \mathrm{C}$ are respectively presented in Figure 8 and Figure 9.

At $1150^{\circ} \mathrm{C}$, a large amount of glassy phase (EDS-A and B) is observed and inactive species such as periclase (EDS-C) are embedded within this glassy phase. The glassy phase is formed of $\mathrm{Ca}, \mathrm{Si}, \mathrm{Al}, \mathrm{Fe}$ and $\mathrm{Mg}$. Particle of $\mathrm{MgO}$ is from de decomposition of dolomite during thermal treatment. This elemental composition is also coherent with the detected minerals (Anorthite, gehlenite and mullite). The observation of mullite is not achieved probably due to a large amount of glassy phase.

At $1200^{\circ} \mathrm{C}$, new phases are clearly observable on the micrographs. The granular aggregates observable on the micrograph in Figure 9, are assigned primary mullite (EDS-D, F, I) [28]. Needles of secondary mullite are also observable (EDS-G). From [32], it is shown that it is primary mullite that evolved to secondary
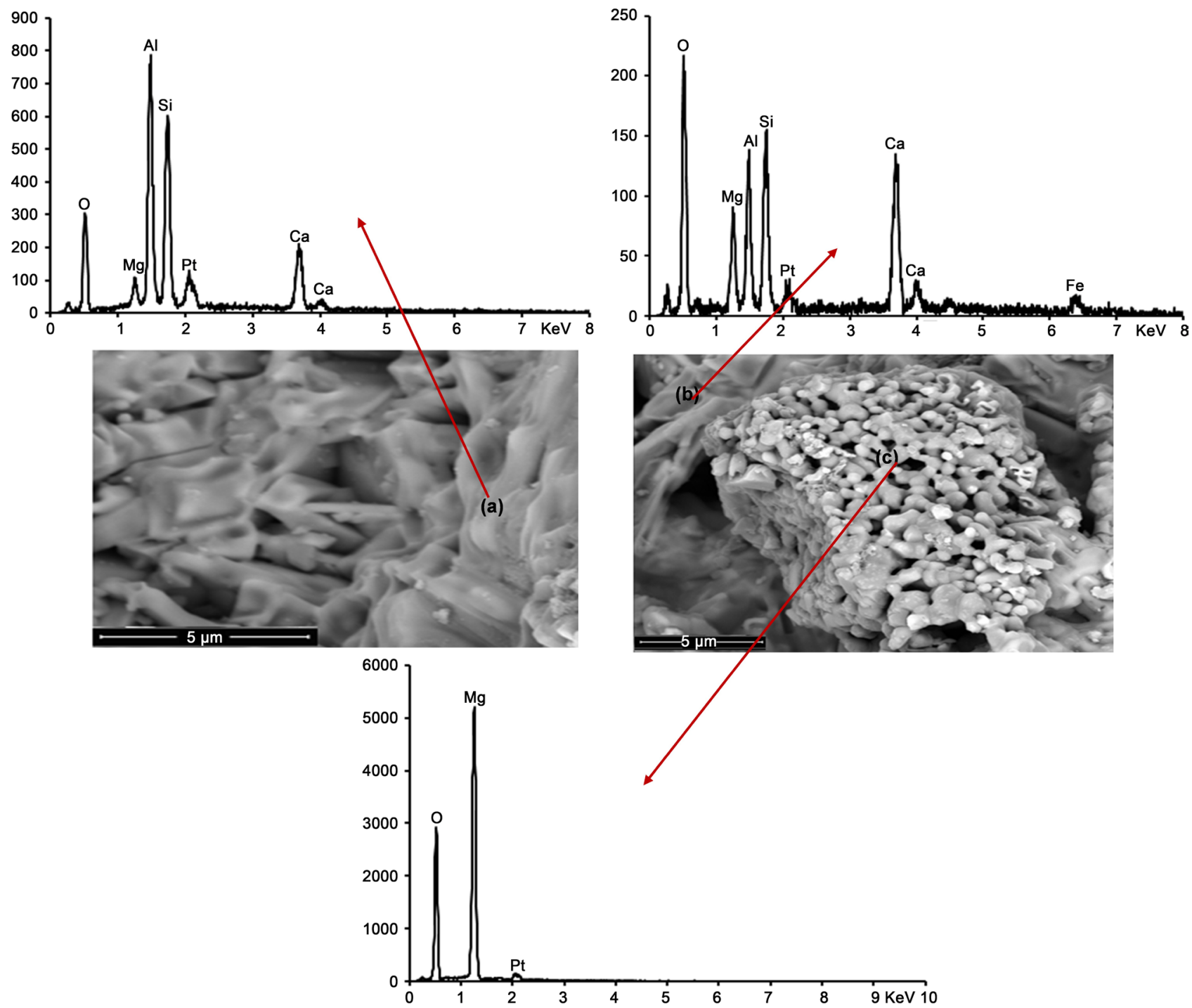

Figure 8. SEM micrographs of fired product at $1150^{\circ} \mathrm{C}$ and EDS analyses ((a) and (b): amorphous phase; (c) periclase) 


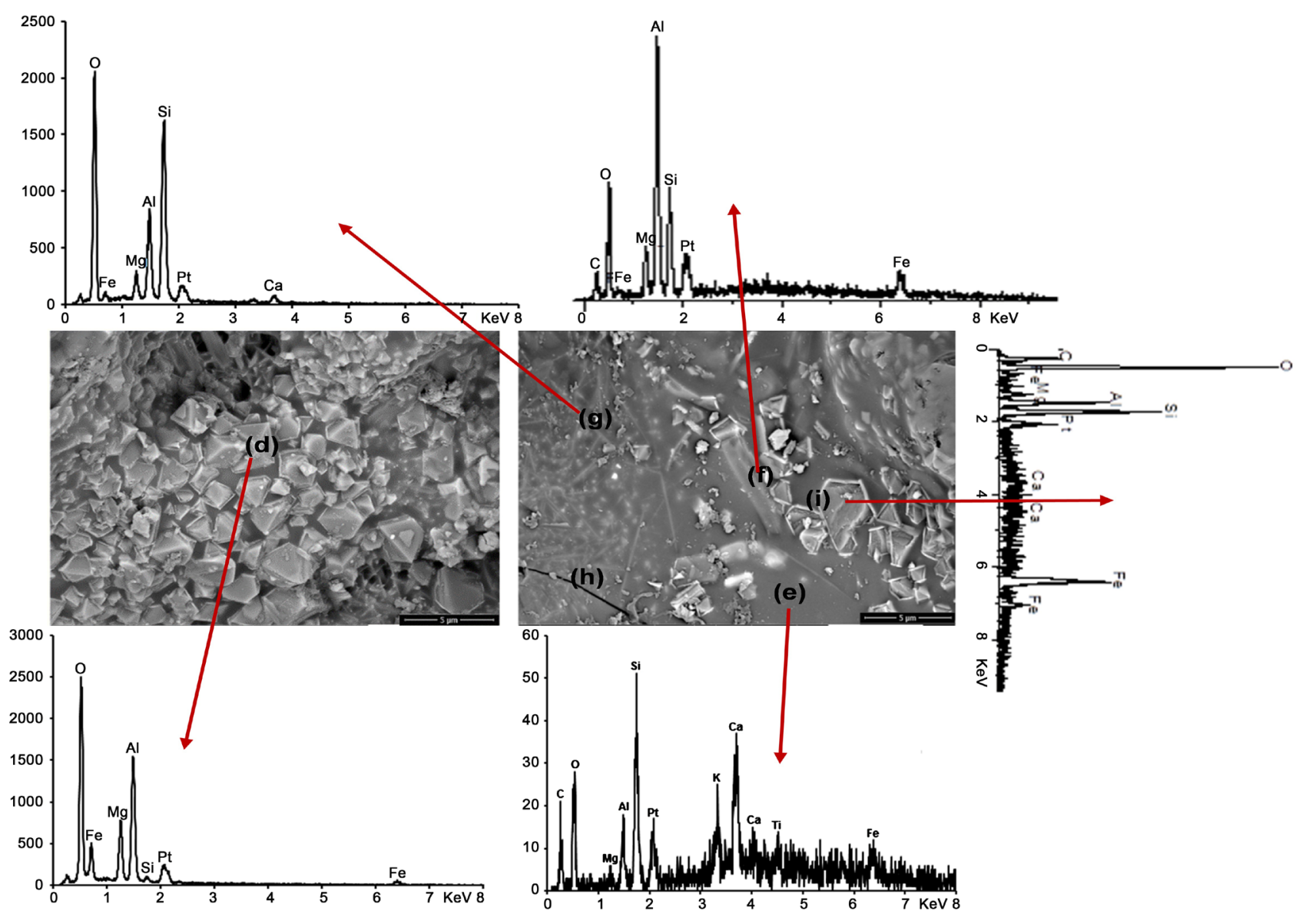

Figure 9. SEM micrographs of fired product at $1200^{\circ} \mathrm{C}$ and EDS analyses on five points ((d), (f), (i) agragtes of granular mullite; (g) needles of mullet and (e) vitreous phase).

mullite; however when vitreous phase is formed both may be found embedded within the vitreous phase. The presence of iron favors the size increase of the mullite as suggested by [24]. The global feature shows a large amount of glassy phase having a chemical composition (EDS-E), coherent with the identified minerals from XRD. The predominance of element $\mathrm{Si}$ in the EDS-E for instance is in agreement with the dissolution of quartz; mullite formation also agree with the predominance of $\mathrm{Al}$ and $\mathrm{Si}$ on EDS on points $\mathrm{G}, \mathrm{F}$ and I. On the EDS of point $\mathrm{D}$, the presence of $\mathrm{Mg}$ and $\mathrm{Al}$ may be associated to the formation of the spinel $\mathrm{MgAl}_{2} \mathrm{O}_{4}$, although non-detected from the XRD pattern.

The abundant glassy phase observable on the micrograph is coherent with the fragile structure revealed from flexural strength. Also, contribution of micro cracks (as point $\mathrm{H}$ in Figure 9) to the weakening is evidence from this image.

\section{Conclusions}

This paper was analyzing the effect of dolomite addition of fired product made from kaolinitic clay of Bangui (Central Africa Republic). The used of technics such as TGA-DTA, ERD and SEM was useful to identified the minerals phased that are formed during firing the mixture M-8. The global sintering behavior 
using dilatometric analysis is similar for both the clay and the clay-dolomite mixture. The densification of the clay or the mixture is marked at $1100^{\circ} \mathrm{C}$ with the formation of mullite and cristobalite. The phase's transformations during thermal treatment are influenced by the materials initial composition. The presence of illite and iron oxide in the clayey material induced liquid phase formation that is favorable to mullite and cristobalite development. A large amount of liquid phase formation, at a higher temperature $\left(1200^{\circ} \mathrm{C}\right)$, induced a fragile behavior that lowers the flexural strength. From SEM observations, the development of large amount of vitreous phase from the mixture is evidence. This formation indicates that the mixture can be used for the development of vitreous ceramic.

The present study, stand as a complementary work by Gonidanga et al. [14], revealed that mixture of dolomite-kaolinite incorporating $8 \%$ (by mass) of dolomite, lead to a large amount of vitreous phase formation that could be useful for the development of other type ceramic products from Bimbo clay. In particular, an optimization of the dolomite will be considered to better formulate mixture for targeted products.

\section{Acknowledgements}

The authors are thankful to:

- The French Ministry of external relation for financing this research through a grant from the Service d'Action Culturelle (SCAC) of the French embassy in CAR;

- The Institute of Research for Ceramic (IRCer) of the University of Limoges (France) is acknowledged for the laboratory facilities;

- Professor Phillipe Blanchart for his assistance in the designing of this work;

- Dr. J.A. Mbey for his assistance in the writing and proof reading of this paper.

\section{Conflicts of Interest}

The authors declare no conflicts of interest regarding the publication of this paper.

\section{References}

[1] Njoya, D., Hajjaji, M., Baçaoui, A. and Njopwouo, D. (2010) Microstructural Characterization and Influence of Manufacturing Parameters on Technological Properties of Vitreous Ceramic Materials. Materials Characterization, 61, 289-295. https://doi.org/10.1016/j.matchar.2009.12.009

[2] Elimbi, A., Founyapte, S. and Njopwouo, D. (2004) Effet de la température de cuisson sur la composition minéralogique et les propriétés physiques et mécaniques de deux matériaux du gisement argileux de Bakong (Cameroun). Annales de Chimie Science des Matériaux, 29, 67-77. https://doi.org/10.3166/acsm.29.2.67-77

[3] Diffo, B.B.K., Elimbi, A., Tchakouté, H.K. and Kumar, S. (2015) Effect of the Rate of Calcination of Kaolin on the Properties of Metakaolin-Based Geopolymers. Journal of Asian Ceramic Societies, 3, 130-138. https://doi.org/10.1016/j.jascer.2014.12.003 
[4] Riccardi, M.P., Messiga, B. and Duminuco, P. (1999) An Approach to the Dynamics of Clay Firing. Applied Clay Science, 15, 393-409. https://doi.org/10.1016/S0169-1317(99)00032-0

[5] Cultrone, G., Rodriguez, N.C., Sebastian, E., Cazalla, O. and De La Torre, M.J. (2001) Carbonate and Silicate Phase Reactions during Ceramic Firing. European Journal of Mineralogy, 13, 621-634. https://doi.org/10.1127/0935-1221/2001/0013-0621

[6] Traoré, K., Kabré, T.S. and Blanchart, P. (2003) Gehlenite and Anorthite Crystallisation from Kaolinite and Calcite Mix. Ceramics International, 29, 377-383. https://doi.org/10.1016/S0272-8842(02)00148-7

[7] Andji, J.Y.Y., Abba Touré, A., Kra, G. and Blanchart, P. (2009) Iron Role on Mechanical Properties of Ceramics with Clays from Ivory Coast. Ceramics International, 35, 571-577. https://doi.org/10.1016/j.ceramint.2008.01.007

[8] Trindale, M.J., Dias, M.I., Coroado, J. and Rocha, F. (2009) Mineralogical Transformations of Calcareous Rich Clays with Firing: A Comparative Study between Calcite and Dolomite Rich Clays from Algarve, Portugal. Applied Clay Science, 42, 345-355. https://doi.org/10.1016/j.clay.2008.02.008

[9] Ptacek, P., Opravil, T., Soukal, F., Havlica, J. and Holsinsky, R. (2013) Kinetics and Mechanism of Formation of Gehlenite, Al-Si Spinel and Anorthite from Mixture of Kaolinite and Calcite. Solid State Sciences, 26, 53-58. https://doi.org/10.1016/j.solidstatesciences.2013.09.014

[10] Cornacchia, M. and Giorgi, L. (1986) Les séries précambriennes d'origine sédimentaire et volcano-sédimentaire de la République Centrafricaine. Ann. Mus. Roy. Afr. Centrale, Tervuren, Belgique, sér, 93, 51 p.

[11] Doyemet, A. (2006) Le système aquifère de la région de Bangui (RCA): Conséquences des caractéristiques géologiques du socle sur la dynamique, le système de recharge et la qualité des eaux souterraines. Thèse de doctorat de l'Université des sciences et technologies de Lille 1 (France).

[12] Ouabégo, K.M. (2013) Contribution à l'étude de la chaine panafricaine des oubanguides en République Centrafricaine, Thèse de doctorat, Université d'Aix Marseille (France), 206 p.

[13] Ndépété, C.P., Zagui-Guerembo, R.L. and Vonto, C.D. (2015) Etude géotechnique des matériaux argileux de Bangui. Presses Académiques Francophones.

[14] Gonidanga, B.S., Njoya, D., Lecomte-Nana, G., Elimbi, A. and Njopwouo, D. (2018) Clay Material from Bimbo (Central Africa Republic (C.A.R)): Physicochemical, Mineralogical Characterization and Technological Properties of Fired Products. European Journal of Scientific Research, 149, 385-400.

[15] Blanchart, P. (2014) Les céramiques silicatées, Article Technique de l'Ingénieur, Faculté des Sciences, Université de Limoges, Réf: N4800 V1.

[16] Darweesh Hassan, H.M. (2001) Building Materials from Siliceous Clay and Low Grade Dolomite Rocks. Ceramics International, 27, 45-50. https://doi.org/10.1016/S0272-8842(00)00040-7

[17] Sedmale, G., Sperberga, I., Sedmalis, U. and Valancius, Z. (2006) Formation of High-Temperature Crystalline Phases in Ceramic from Illite Clay and Dolomite. Journal of the European Ceramic Society, 26, 3351-3355. https://doi.org/10.1016/j.jeurceramsoc.2005.10.012

[18] Ke, S., Cheng, X., Wang, Y., Wang, Q. and Wang, H. (2013) Dolomite, Wollastonite and Calcite as Different $\mathrm{CaO}$ Sources in Anorthite-Based Porcelain. Ceramics International, 39, 4953-4960. https://doi.org/10.1016/j.ceramint.2012.11.091 
[19] Huang, C.K. and Keer, P.F. (1960) Infrared Study of the Carbonate Minerals. American Mineralogist, 45, 311-324.

[20] Hajjaji, M. (2014) Mineralogy and Thermal Transformations of Clayey Materials from the District of Marrakech, Morocco. Comunicaçoes Geologicas, 101, 75-80.

[21] Sei, J. (1998) Etude de matériaux de dimensionnalité réduite: Relation structurepropriétés dans des kaolinites naturelles de Cote d'Ivoire, Thèse de doctorat de l'Université de Montpellier.

[22] Caillere, S., Henin, S. and Rautereau, M. (1963) Minéralogie des Argiles, Ed. Masson and $\mathrm{Cie}$.

[23] Caillere, S., Henin, S. and Rautureau, M. (1989) Les argiles. Ed. Septima, Paris.

[24] Soro, N.S. (2003) Influence des ions fer sur les transformations thermiques de la kaolinite. Thèse de doctorat de l'Université de Limoges (France), 158 p.

[25] Valette, S. (2015) Techniques de caractérisation des céramiques. Article, Techniques de l'Ingénieur, Université de Limoges, Ref: N4806 V1.

[26] Chen, C.Y., Lan, G.S. and Tuan, W.H. (2000) Microstructural Evolution of Mullite during the Sintering of Kaolin Powder Compacts. Ceramics International, 26, 715-720. https://doi.org/10.1016/S0272-8842(00)00009-2

[27] Deniel, S. (2010) Elaboration et caractérisation de céramiques textures de mullite à partir de phyllosilicates, Thèse de doctorat de l'Université de Limoges (France), $204 \mathrm{p}$.

[28] Castelein, O. (2000) Influence de la vitesse du traitement thermique sur le comportement d'un kaolin: Application au frittage rapide. Thèse de doctorat de l'Université de Limoges (France), 142 p.

[29] Sokôlar, R., Vodova, L., Grygarova, S., Stubua, I. and Peter, S. (2012) Mechanical Properties of Ceramics Bodies Based on Calcite Waste. Ceramic International, 38, 6607-6612. https://doi.org/10.1016/j.ceramint.2012.05.046

[30] Aliprandi, G. (1979) Matériaux réfractaires et céramiques techniques, Septima, Paris, $612 \mathrm{p}$.

[31] Khalil, A.A. and Kabesh, A.M. (1981) The Use of Whadi Gharandel Deposits for Various Ceramics Products; III: Physical and Mechanical Properties of the Prepared Ceramics Bodies. Sprechsaal, 114, 414-417.

[32] Schûller, K.H. (1963) Reaction between Mullite and Glass Phase in Porcelain. Joint Meet with Society of Glass Technology, Cambridge. 